\title{
MOTIVASI MAHASISWA PRODI PENDIDIKAN JASMANI KESEHATAN DAN REKREASI MENJAGA KEBUGARAN JASMANI PADA MASA PANDEMI COVID-19
}

\author{
Ni Komang Alit Tri Candra Dewi ${ }^{1}$, I.K. Budaya Astra ${ }^{2}$, I.G. Suwiwa ${ }^{3}$ \\ ${ }^{1,2,3}$ Program Studi Penjaskesrek Jurusan Pendidikan Olahraga, \\ Fakultas Olahraga dan Kesehatan \\ Universitas Pendidikan Ganesha, \\ Singaraja-Indonesia \\ Email : komangalitcandra@gmail.com¹, budaya.astra@undiksha.ac.id ${ }^{2}$, \\ suwiwagede@undiksha.ac.id ${ }^{3}$
}

\begin{abstract}
ABSTRAK
Penelitian ini bertujuan untuk menganalisis motivasi mahasiswa prodi pendidikan jasmani, kesehatan, dan rekreasi fakultas olahraga dan kesehatan menjaga kebugaran jasmani pada masa pandemi covid-19. Pada masa pandemi covid-19 dapat mempengaruhi pada kebugaran jasmani mahasiwa, dengan adanya surat edaran pemerintah tentang phisical distancing maka mahasiswa mendapat kendala pada saat berolahraga. Penelitian ini adalah penelitian deskriptif kuantitatif dengan jenis penelitian survei. Populasi penelitian adalah mahasiswa semester II, sampai VII tahun akademik 2019/2020 di prodi pendidikan jasmani, kesehatan, dan rekreasi, fakultas olahraga dan kesehatan dengan jumlah 322 orang. Sampel penelitian menggunakan quota sampling dengan besaran $20 \%$ dari total populasi sehingga jumlah sample dalam penelitian ini adalah 64. Data dianalisis menggunakan statistik deskriptif kuantitatif dengan persentase dengan bantuan microsoft office exel 2007. Hasil analisis dalam penelitian ini menyatakan bahwa motivasi intriksik mendapatkan skor $86 \%$ dan motivasi ekstrinsik mendapatkan skor $80 \%$ dalam skala penilaian katagori dinyatakan sangat tinggi. Dari kedua indikator pada variabel motivasi memperoleh skor $83 \%$ pada interval katagori dikatakan sangat tinggi. Saran dari peneliti untuk mahasiswa agar meningkatkan motivasi untuk melaksanakan aktivitas abstract
\end{abstract}

Kata Kunci: Motivasi, Kebugaran Jasmani, Pandemi Covid-19

\section{ABSTRACT}

This study aims to analyze the motivation of students from the physical education, health and recreation department of the sports and health faculty to maintain physical fitness during the Covid-19 pandemic. During the Covid-19 pandemic it can affect the physical fitness of students, with the existence of a government circular about physical distancing, students have problems when exercising. This research is a descriptive quantitative research with survey research type. The study population was students of semester II, to VII of the 2019/2020 academic year in the physical education, health and recreation study programs, sports and health faculty with a total of 322 people. The research sample used quota sampling with a size of $20 \%$ of 
the total population so that the number of samples in this study was 64.Data were analyzed using quantitative descriptive statistics with percentages with the help of Microsoft Office Excel 2007. The results of the analysis in this study stated that intricate motivation got a score of $86 \%$ Extrinsic motivation got a score of $80 \%$ on the category rating scale which was declared very high. Of the two indicators on the motivation variable, the score was $83 \%$ at the category interval which was said to be very high. Suggestions from researchers for students to increase motivation to carry out abstract activities

Keywords: Motivation, Physical Fitness, Covid-19 Pandemic

\section{PENDAHULUAN}

Kebugaran jasmani merupakan kecocokan keadaan fisik terhadap tugas yang harus dilaksanakan oleh fisik atau jasmani berdasarkan syarat-syarat fisik yang bersifat anatomis, fisiologis, kesesuaian anatomik dan kesesuaian fisiologik. Kebugaran jasmani lebih bertitik berat pada physiological fitness, sehingga dapat didefiniskan tingkat kesesuaian derajat sehat dinamis yang dimiliki oleh pelaksana terhadap beratnya tugas fisik yang harus dilaksanakan. Kebugaran jasmani yang baik akan menjamin seseorang dalam melaksanakan tugasnya menjadi lebih siap dan selalu menampakkan penampilan yang optimal, serta mempunyai semangat hidup yang tinggi. Menurut Suroto (2004:2) menyatakan bahwa kebugaran jasmani merupakan kemampuan atau kesanggupan seseorang untuk melakukan aktivitas atau kegiatan dengan daya kerja tinggi dengan tanpa mengalami kelelahan yang berarti atau berlebihan. Menurut arma abdoellah (2005:47) menyatakan bahwa ada dua definisi yang bisa digunakan, dari sudut pandang fisiologis kebugaran jasmani adalah kapasitas untuk dapat menyesuaikan diri terhadap latihan yang melelahkan dan pulih dari latihan tersebut. Definisi kebugaran jasmani yang lebih umum adalah kemampuan untuk dapat melaksanakan tugas sehari-hari dengan semangat, tanpa rasa lelah yang berlebihan dan dengan penuh energi melakukan dan menikmati kegiatan pada waktu luang, dan dapat menghadapi keadaan darurat bila datang. Jadi dapat disimpulkan kebugaran jasmani merupakan kemampuan seseorang melakukan aktivitas sehari-hari secara efisien tanpa menimbulkan kelelahan yang berlebihan sehingga dapat menyesuaikan fungsi alat-alat tubuhnya dan masih dapat menikmati waktu luang. Tujuan utama dari latihan kebugaran jasmani adalah untuk mempertahankan dan meningkatkan tingkat kebugaran jasmani. Unsur-unsur kebugaran jasmani yang berhubungan dengan konsep kebugaran jasmani dalam kehidupan sehari-hari terdiri dari kekuatan, kelenturan, dan keseimbangan. Bentuk ini akan diuraikan bentuk-bentuk latihan kekuatan, kelenturan, dan keseimbangan yang dapat dilakukan dengan cara yang mudah dan murah, namun menghasilkan kebugaran yang maksimal apabila dilakukan dengan benar, teratur, dan dalam jangka waktu yang lama. Setiap orang selalu membutuhkan alasan yang mampu menguatkan dirinya untuk memulai bertindak dan tetap konsisten sampai tercapainya tujuan yang diinginkan. Motivasi yang dibutuhkan seseorang merupakan suatu dorongan yang mengarahkan seseorang untuk berbuat lebih pada dirinya sendiri. Menurut Hamzah B. Uno (2012:1) menyatakan 
bahwa motivasi adalah kekuatan, baik dari dalam maupun dari luar yang mendorong seseorang untuk mencapai tujuan yang telah ditetapkan sebelumnya. Menurut sugiharto dkk, (2007:78) menyatakan bahwa motivasi merupakan suatu kondisi yang menyebabkan atau menimbulkan perilaku tertentu dan memberi arah dan ketahanan pada tingkah laku. Djaali (2007:101) menyatakan motivasi merupakan proses membangkitkan, mengarahkan, dan memantapkan prilaku arah satu tujuan. Dari peryataan diatas motivasi merupakan suatu proses yang menjelaskan tentang arah, ketekunan seseorang individu untuk mencapai tujuan dan pencapaian dalam dirinya. Kuat lemahnya motivasi seseorang mempengaruhi keberhasilannya. Karena itu motivasi perlu diusahakan terutama yang berasal dari dalam diri seseorang dengan senantiasa memikirkan masa depan yang harus dihadapi untuk mencapai cita-cita.

Masyarakat dunia tengah diresahkan dengan adanya wabah Corona Virus Disease (Covid-19) yang menjadi sebuah pandemi. Seluruh dunia kini disibukkan dengan berbagai upaya pencegahan Covid-19 untuk menahan lonjakan pasien positif karena hingga saat ini masih belum ditemukan obat maupun vaksinnya. Selain itu dengan adanya virus Covid-19 pemerintah membuat beberapa kebijakan untuk menghentikan penyebaran wabah ini, seperti melakukan lockdown di daerah yang sudah termasuk kedalam zona merah penyebaran virus, lalu physical quarantine untuk mnghindari penyebaran virus secara kontak fisik. Novel Corona Virus 2019 (N-Covid 19 ) yang biasa disebut dengan virus corona adalah penyakit menular yang disebabkan oleh SARS-COV-2, salah satu jenis corona virus dimana penyakit ini telah menjadi pandemic ditahun
2019-2020. Gejala corona virus muncul dalam 2-14 hari setelah paparan ditandai dengan gejala gangguan pernapasan akut seperti demam, batuk, dan sesak napas, pada kasus berat menyebabkan pneumonia. sindrom pernapasan akut, gagal ginjal, bahkan kematian (WHO, Materi Komunikasi Risiko Covid-19 untuk Fasilitas Pelayanan Kesehatan, 2020). Persebaran Covid-19 yang begitu massif di berbagai Negara telah memaksa masyarakat untuk melihat fakta bahwa dunia sedang berubah. Tidak hanya itu, mereka harus melihat pula perubahan-perubahan dibidang sosial,ekonomi, politik, hukum hingga bidang pendidikan ikut berduka di tengah-tengah kisis akibat sebaran Covid-19. Penyakit yang ditimbulkan oleh Novel Corona Virus 2019 (Covid19) adalah penyakit yang menular yang disebabkan oleh SARS-COV-2, salah satu jenis korona virus dimana penyakit ini telah menjadi pademi ditahun 20192020. Infeksi menyebar dari satu orang ke orang lain melalui percikan (droplet) dari saluran pernapasan yang sering dihasilkan saat batuk atau bersin. Sejak merebaknya pandemi yang disebabkan oleh virus corona di Indonesia, banyak cara yang dilakukan oleh pemerintah untuk mencegah penyebarannya. Salah satunya dengan melalui surat edaran Kementrian Pendidikan dan Kebudayaan (Kemendikbud) Direktorat Tinggi No 1 tahun 2020 tentang pencegahan penyebaran Corona Virus Disease (Covid-19) di perguruan tinggi melalui surat edaran tersebut memberikan instruksi kepada perguruan tinggi untuk menyelenggarakan pembelajaran jarak jauh dan menyarankan mahasiswa untuk belajar diumah masing-masing. Dengan persebaran pandemi covid-19 yang begitu cepat melanda dunia hal ini menyebabkan dosen dan mahasiswa mau tidak mau berjuang dengan keadaan ini. Situasi yang sebelumnya 
proses pembelajaran berlangsung dengan tatap muka, dengan bimbingan langsung bertemu fisik dengan proses dikelas menjadi suatu hal yang tidak bisa dilaksanakan lagi.

Pelaksanaan aktivitas belajar dirumah dengan media daring menuntut mahasiswa menguasai media yang beragam. Dengan keberanekaragaman media daring yang sebelumnya belum pernah menggunannya, mahasiswa dituntut untuk bisa menguasainya. Perkuliahan online yang beragam mengakibatkan pengguna media yang beragam pula. Pemanfaatan pembelajaran kebugaran jasmani dalam bentuk multimedia disebuah mobilephone. Teknologi atau lebih tepatnya internet, ponsel pintar dan laptop sekarang digunakan secara luas untuk mendukung aktivitas jasmani. Salah satu penyediaan jasa telekomunikasi terbesar di Indonesia mencatat peningkatan arus broadband sebesar $16 \%$ selama krisis Covid-19, yang disebabkan oleh tajamnya peningkatan penggunaan aplikasi kebugaran.

Seiring dengan perkembangan zaman kemajuan teknologi informasi dan komunikasi ini berlangsung dengan cepat dan menawarkan banyak kemudahan bagi manusia dalam memperoleh informasi. Perbedaan jarak, waktu, dan tempat tidak lagi menjadi kendala dalam memperoleh informasi. Pemanfaatan aktivitas kebugaran jasmani dalam bentuk multimedia disebuah m-learning pada aktivitas jasmani ini diharapkan dapat melatih dan membantu mahasiswa dalam menjaga kebugaran jasmani pada masa pandemi Covid-19 ini. Smartphone merupakan benda yang akrab dengan kehidupan manusia di setiap harinya. Dalam menjaga kebugaran jasmani mahasiswa dapat memanfaatkan smartphone dalam mempermudah melakukan kegiatan aktivitas jasmani. Pada masa pandemi covid-19 ini bisa mempengaruhi kebugaran jasmani mahasiswa Prodi Pendidikan Jasmani Kesehatan dan Rekreasi. Untuk itu mahasiswa Prodi Pendidikan Jasmani Kesehatan dan Rekreasi perlu menjaga kebugaran jasmani dengan beraktivitas. Namun dengan keterbatasan dalam melakukan aktivitas jasmani, maka peneliti bertujuan ingin mengetahui Motivasi mahasiswa Prodi Pedidikan Jasmani Kesehatan dan Rekreasi dalam menjaga kebugaran jasmani pada masa pandemi covid-19 ini.

Berdasarkan latar belakang di atas, adapun tujuan penelitian ini adalah "untuk mengetahui seberapa besar Motivasi Mahasiswa Prodi Pendidikan Jasmani Kesehatan dan Rekreasi Fakultas Olahraga dan Kesehatan Menjaga Kebugaran Jasmani Pada Masa Pandemi Covid-19 “.

\section{METODE PENELITIAN}

Penelitian ini merupakan penelitian deskriptif kuantitatif dengan jenis penelitian survei. Dalam penelitian ini peneliti tidak memberikan perlakuan, tetapi langsung mengambil data dari sumber data. Penelitian ini dirancang untuk mendeskripsikan dan menjelaskan tentang kondisi motivasi mahasiswa dalam menjaga kebugaran jasmani di masa pandemi covid-19.

Metode pengumpulan data pada penelitian ini adalah Pengumpulan data dilakukan dengan menggunakan instrument penilaian berupa angket untuk mengidentifikasi motivasi mahasiswa Prodi Pendidikan Jasmani Kesehatan Dan Rekreasi, Fakultas Olahraga Dan Kesehatan. Penilaian berupa angket ini berisi bagian isi dan bagian alasan. Bagian pertama memuat respon mahasiswa terhadap pilihan pada angket yang disediakan yang berkaitan dengan konten. Penyebaran angket menggunakan goggle form. Kuisioner ini menggunakan skala likert 
dengan 4 dimensi penilaian yaitu sangat setuju (SS), setuju (S), tidak setuju (TS), dan sangat tidak setuju (STS).

Dalam penelitian ini instrument yang digunakan adalah angket yang berisi pernyataan yang digunakan untuk mengungkap motivasi mahasiswa untuk menjaga kebugaran jasmani ditinjau dari faktor instrinsik (rasa tertarik, perhatian, aktivitas ) dan faktor ekstrinsik lingkungan dan alat atau fasilitas).

Populasi penelitian adalah mahasiswa semester II, IV, VI, VIII tahun akademik 2019/2020 di Prodi Pendidikan Jasmani, Kesehatan, dan Rekreasi, Fakultas Olahraga dan Kesehatan dengan jumlah keseluruhan 322 orang. Sampel penelitian menggunakan non random sampling yaitu quota sampling dengan besaran $20 \%$ dari total populasi sehingga jumlah sample dalam penelitian ini adalah 64 Data dianalisis menggunakan statistik deskriptif kuantitatif dengan katagori interval dengan bantuan Microsoft office exel 2007. Analisis deskriptif digunakan untuk mengetahui motivasi mahasiswa berdasarkan deskriptif frekuensi, sehingga diketahui frekuensi, persen dan nilai serta katagori lainnya, dengan skala penilaian katagori dengan diklasifikasikan sebagai berikut: Sangat tinggi, tinggi, sedang.

\section{HASIL DAN PEMBAHASAN}

Motivasi mahasiswa Prodi
Pendidikan Jasmani Kesehatan dan
Rekreasi Fakultas Olahraga dan
Kesehatan menjaga kebugaran jasmani
pada masa pandemi covid-19 telah
diukur menggunakan angket yang terdiri
dari 20 butir pernyataan. Berikut hasil
analisis deskriptif data Motivasi
mahasiswa Prodi Pendidikan Jasmani
Kesehatan dan Rekreasi
Olahragaltas
kebugaran jasmani pada masa pandemi
covid-19 yang disajikan pada Tabel

Tabel 1. Hasil Analisis Data

\begin{tabular}{|c|c|c|c|c|c|c|c|c|}
\hline \multirow{2}{*}{$\begin{array}{l}\mathbf{N} \\
\mathbf{0}\end{array}$} & \multirow{2}{*}{ Pernyataan } & \multicolumn{4}{|c|}{ Tangapan responden } & \multirow[b]{2}{*}{$\mathbf{N}$} & \multirow{2}{*}{ Presentase } & \multirow{2}{*}{ Kat } \\
\hline & & SS & $\mathrm{S}$ & TS & STS & & & \\
\hline 1. & $\begin{array}{l}\text { Saya butuh berolahraga } \\
\text { pada masa pandemi } \\
\text { covid-19. }\end{array}$ & 54 & 10 & 0 & 0 & 64 & $96 \%$ & $\begin{array}{l}\text { Sangat } \\
\text { Tinggi }\end{array}$ \\
\hline 2. & $\begin{array}{l}\text { Saya ingin melakukan } \\
\text { aktivitas jasmani dengan } \\
\text { mudah. }\end{array}$ & 41 & 23 & 0 & 0 & 64 & $91 \%$ & $\begin{array}{l}\text { Sangat } \\
\text { Tinggi }\end{array}$ \\
\hline 3. & $\begin{array}{l}\text { Aktivitas jasmani } \\
\text { merupakan aktivitas } \\
\text { yang menjenuhkan. }\end{array}$ & 2 & 2 & 39 & 21 & 64 & $81 \%$ & $\begin{array}{l}\text { Sangat } \\
\text { Tinggi }\end{array}$ \\
\hline 4. & $\begin{array}{l}\text { Aktivitas jasmani } \\
\text { memberikan hal yang } \\
\text { positif pada diri saya. }\end{array}$ & 53 & 11 & 0 & 0 & 64 & $96 \%$ & $\begin{array}{l}\text { Sangat } \\
\text { Tinggi }\end{array}$ \\
\hline 5. & $\begin{array}{l}\text { Saya tertarik untuk } \\
\text { mencari aplikasi } \\
\text { kebugaran jasmani. }\end{array}$ & 31 & 32 & 1 & 0 & 64 & $87 \%$ & $\begin{array}{l}\text { Sangat } \\
\text { Tinggi }\end{array}$ \\
\hline 6. & $\begin{array}{l}\text { Saya tertarik untuk } \\
\text { melakukan aktivitas } \\
\text { jasmani yang mudah. }\end{array}$ & 34 & 29 & 1 & 0 & 64 & $88 \%$ & $\begin{array}{l}\text { Sangat } \\
\text { Tinggi }\end{array}$ \\
\hline 7. & $\begin{array}{l}\text { Saya tertarik untuk } \\
\text { memperhatikan teknik- }\end{array}$ & 33 & 31 & 0 & 0 & 64 & $88 \%$ & $\begin{array}{l}\text { Sangat } \\
\text { Tinggi }\end{array}$ \\
\hline
\end{tabular}




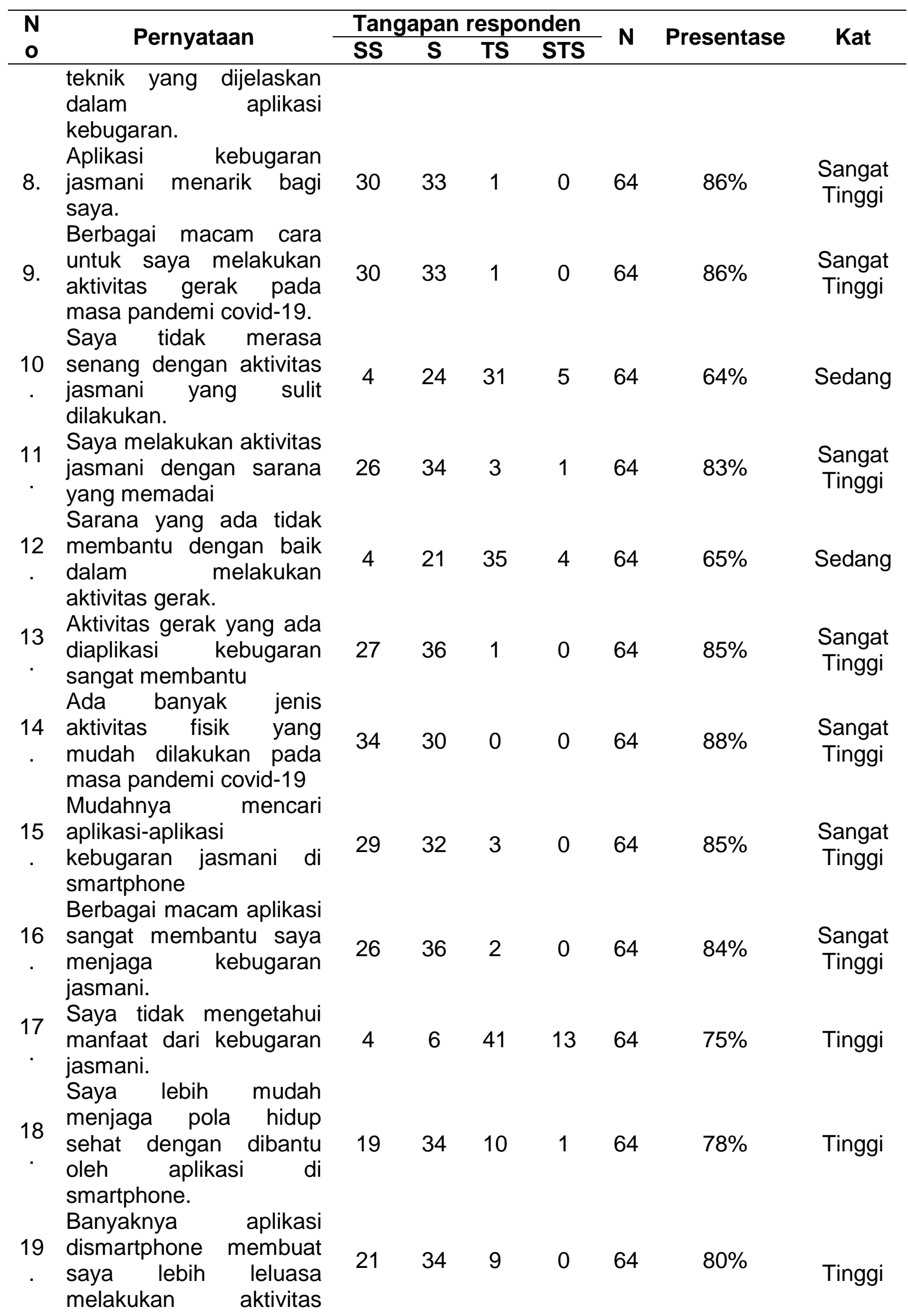




\begin{tabular}{|c|c|c|c|c|c|c|c|c|}
\hline \multirow{2}{*}{$\begin{array}{l}\mathbf{N} \\
\mathbf{0}\end{array}$} & \multirow{2}{*}{ Pernyataan } & \multicolumn{4}{|c|}{ Tangapan responden } & \multirow{2}{*}{$\mathbf{N}$} & \multirow{2}{*}{ Presentase } & \multirow{2}{*}{ Kat } \\
\hline & & SS & s & TS & STS & & & \\
\hline 20 & $\begin{array}{l}\text { gerak. } \\
\text { Saya menggunakan } \\
\text { bantuan smartphone } \\
\text { untuk menjaga dan } \\
\text { meningkatkan kebugaran } \\
\text { jasmani di rumah saja } \\
\text { pada masa pandemic } \\
\text { covid-19 }\end{array}$ & 19 & 37 & 7 & 1 & 64 & $79 \%$ & Tinggi \\
\hline
\end{tabular}

Berdasarkan Tabel 2 pada indikator faktor instriksik sebanyak 64 orang begitu pula pada indikator faktor ekstrinsik sebanyak 64 orang. Dari hasil analisis responden 10 pernyataan motivasi instriksik diatas, bila dirata- ratakan memperoleh rata-rata skor 86 dan 10 pernyataan motivasi eksrinsik bila dirata-ratakan memperoleh rata-rata skor 80 Bila dikonversikan pada skala penilaian katagori katagori berada pada katagori sangat tinggi.

Tabel 2. Hasil Analisis Deskriptif

\begin{tabular}{ccccc}
\hline No. & Indikator & Banyak siswa & Presentase & Katagori \\
\hline 1. & Faktor Instrinsik & 64 & $86 \%$ & Sangat Tinggi \\
2. & Faktor Ekstrinsik & 64 & $80 \%$ & Sangat Tinggi \\
\hline
\end{tabular}

Penelitian ini bertujuan untuk mengetahui seberapa besar motivasi mahasiswa Prodi Pendidikan Jasmani Kesehatan dan Rekreasi Fakultas Olahraga dan Kesehatan menjaga kebugaran jasmani pada masa pandemi covid-19. Pada masa pandemi covid-19 dapat mempengaruhi kebugaran jasmani mahasiswa, yang dikarenakan adanya virus corona yang tersebar di seluruh dunia. virus ini dapat menyerang kekebalan tubuh dan dengan adanya surat edaran pemerintah tentang pembatasan kegiatan atau sosial distancing mahasiswa dan masyarakat akan mendapat kendala dalam melakukan aktivitas di luar rumah termasuk aktivitas jasmani.

Berdasarkan hasil analisis data kedua indikator pada variabel motivasi mahasiswa prodi Pendidikan Jasmani Kesehatan dan Rekreasi Fakultas Olahraga dan Kesehatan memperoleh nilai $83 \%$. Sehingga motivasi mahasiswa Prodi Pendidikan Jasmani Kesehatan dan Rekreasi Pada skala penilaian katagori dikatakan sangat tinggi, Hasil ini menunjukkan bahwa motivasi dari mahasiswa dalam menjaga kebugaran jasmani pada masa pandemi covid-19 sudah sebagian besar memiliki motivasi dalam menjaga kebugaran dan mahasiswa termotivasi dengan bantuan aplikasi-aplikasi dalam melaksanakan aktivitas jasmani walaupun hanya dirumah saja dan mempengaruhi juga kebugaran jasmani mahasiswa sehingga mahasiswa dapat terhindar dari paparan virus covid-19. Motivasi merupakan dorongan yang melibatkan kesiapan pada diri sendiri dalam kondisi fisik dan psikis untuk melakukan suatu hal agar mencapai tujuan tertentu.

Mahasiswa Prodi Pendidikan Jasmani Kesehatan Dan Rekreasi Fakultas Olahraga Dan Kesehatan sangat dipengaruhi oleh faktor dalam diri dan luar diri untuk mencapai tujuan menjaga kebugaran jasmani pada masa pandemi covid-19. Kecendrungan yang terjadi bahwa pengaruh mahasiswa yang datang dari dalam diri lebih besar 
dari luar diri mahasiswa tersebut meliputi kebutuhan, pengalaman, perhatian, rasa tertarik dan kenyaman dalam melakukan aktivitas jasmani.

Sejalan dengan hasil penelitian Herman Subarjah (2016) hubungan antara kebugaran jasmani dan motivasi belajar dengan prestasi belajar mahasiswa terdapat hubungan yang positif antara motivasi belajar dengan kebugaran jasmani. Dan hasil penelitian Meiria Zuraida, Irwandi, Abdurrahman (2016) motivasi instriksik masyarakat dalam mengikuti senam aerobik di stadion harapan bangsa banda aceh menyatakan bahwa motivasi masyarakat sangat baik dan berantusias dalam mengikuti aktivitas olahraga senam aerobik. dan Penelitian oleh Moch Fahmi Abdulaziz, dkk (2016) motivasi mahasiswa terhadap aktivitas olahraga pada sore hari di sekitar area taman sutera Universitas Negeri Semarang menyatakan bahwa motivasi mahasiswa melakukan aktivitas olahraga disekitar area taman sutera karena kubutuhan akan rasa aman, sehingga mahasiswa termotivasi melakukan aktivitas olahraga agar dapat mempertahankan kondisi fisiknya.

Kebiasaan pola hidup mahasiswa juga mempengaruhi pola aktivitas jasmani dengan adanya pengaruh dari motivasi tersebut akan menjadi pendorong bagi mahasiswa untuk tetap menjaga kebugaran jasmani dan terhindar dari paparan virus covid-19 dengan tetap melakukan aktivitas jasmani. Dari sebuah kesukaan terhadap olahraga, maka akan mempengaruhi mahasiswa yang akan berimbas pada munculnya motivasi dalam berolahraga. Perubahan perilaku pada mahasiswa dari tidak suka menjadi suka dan dari tidak butuh menjadi butuh akan menunjukkan bahwa terjadi perubahan yang kuat dalam diri mahasiswa. Faktor dari dalam dan dari luar sangat mempengaruhi tingkat motivasi mahasiswa terhadap sesuatu seperti aktivitas berolahraga.

\section{PENUTUP}

Berdasarkan hasil analisis data menggunakan deskriptif kuantitatif dapat disimpulkan bahwa motivasi mahasiswa prodi Pendidikan Jasmani Kesehatan dan Rekreasi Fakultas Olahraga dan Kesehatan mengaja kebugaran jasmani pada masa Pandemi Covid -19 adalah memperoleh nilai $83 \%$ terhitung dari jumlah persentase motivasi intrinsik dan motivasi ekstrinsik, dan pada skala penilaian katagori dikatakan sangat tinggi.

Berdasarkan kesimpulan penelitian di atas, adapun saran yang dapat diberikan adalah sebagai berikut: Bagi mahasiswa diharapkan agar meningkatkan motivasi untuk melakukan aktivitas jasmani dalam menjaga kebugaran jasmani pada masa pandemi covid-19 sehingga dapat menjaga kesehatan diri dan mencegah penularan covid-19 dengan meningkatkan daya tahan tubuh melalui aktivitas fisik. Bagi peneliti lain yang berminat mengadakan penelitian deskriptif kuantitatif tentang survei motivasi mahasiswa dalam menjaga kebugaran jasmani pada masa pandemi covid-19 menjadikan hasil penelitian ini sebagai salah satu referensi untuk meneliti dalam lingkup yang lebih luas, sehingga diperoleh sumbangan ilmu yang lebih baik dan sesuai dengan perkembangan zaman dan diperoleh dalam penelitian lebih objektif. Dan bagi dosen diharapkan agar memotivasi mahasiswa melalui media virtual untuk melakukan aktivitas jasmani dalam menjaga kebugaran jasmani pada masa pandemi covid-19 sehingga mahasiswa termotivasi dan dapat mejaga kesehatan diri dan mencegah penularan covid-19. 


\section{DAFTAR PUSTAKA}

Abdoellah, A. (2005). Kebugaran Jasmani dan Perkembangan IImu Pengetahuan dan Teknologi dalam Masyarakat. Jurnal Pendidikan Jasmani Indonesia, 2(2).

Abdulaziz, Moch Fahmi, dkk. 2016. "Motivasi Mahasiswa Terhadap Aktivitas Olahraga Pada Sore Hari di Sekitar Area Taman Sutera Universitas Negeri Semarang". Journal of Physical Education, Health and Sport. $3,(2)$.

Ahmadi, Abu dan Munawar Sholeh. 2005. Psikologi Perkembangan. Jakarta : Rineka Cipta

Arikunto, Suharsini, 2006. "Prosedur Penelitian Suatu Pendekatan Praktik'. Jakarta : PT Rineka Cipta

Arikunto, Suharsini, 2014. "Prosedur Penelitian Suatu Pendekatan Praktik'. Jakarta : PT Rineka Cipta

Djaali.2007. Psikologi Pendidikan. Jakarta: PT Bumi Perkasa.

Firman, Sari Rahayu Rahman. 2020. "Pembelajaran online ditengah pandemic covid-19". Indonesian Journal of Edutational Science (IJES) 2,(2).

Ikhwan, A. N. Penggunaan Software Dalam Pembelajaran Kampus Di Masa Pandemi Covid-19: Studi Literatur.

Kanca, I Nyoman. 2010. Metodologi Penelitian Pengajaran Pendidikan Jasmani dan
Olahraga. Singaraja: Universitas Pendidikan Ganesha

Koyan. I Wayan. 2012. Statistika Pendidikan Teknik Analisis Data Kuantitatif. Singaraja: Universitas Pendidikan Ganesha

Subarjah, Herman. 2016. "Hubungan Antara Kebugaran Jasmani Dan Motivasi Belajar Dengan Prestasi Belajar Mahasiswa" Jurnal Pendidikan Sains Sosial dan Kemanusiaan. 9, (1).

Slameto. 2015. Metodelogi Penelitian \& Inovasi Pendidikan. Salatiga:Cipta

Sugiyono. 2009. Metodelogi Penelitian Kuantitatif, Kualitatif Dan R\&D, Bandung: Alfabet.

Suroto. 2004. Peningkatan Kebugaran melalui kegiatan senam aerobic dan skj 2004. Semarang. Universitas Diponegoro

Uno, Hamzah B. 2012. Teori Motivasi \& Pengukurannya. Jakarta: PT Bumi Aksara

Zuraida, Meira dkk. 2015: "Motivasi Intrinsik Masyarakat Dalam Mengikuti Senam Aerobik di Stadion Harapan Bangsa Banda Aceh tahun 2015". Jurnal IImiah Mahasiswa Program Studi Pendidikan Jasmani Kesehatan dan Rekreasi. Volume 2, Nomor 2. 